\title{
A fahéjkéreg-illóolaj alkalmazhatósága légúti betegségek esetén - pécsi tapasztalatok
}

Horváth Györgyi ${ }^{1, *}$, Ács Kamilla ${ }^{1}$, Balázs Viktória Lilla ${ }^{1}$, Csikós Eszter ${ }^{1}$, Ashraf Amir Reza $^{1}$, Kocsis Béla ${ }^{2}$, Böszörményi Andrea ${ }^{3}$, Horváth Barbara ${ }^{4}$, Széchenyi Aleksandar ${ }^{4}$, Kereskai Lászlón, Csekö Kata $^{6}$, Kemény Ágnes $^{6}$, Helyes Zsuzsanna ${ }^{6,7}$

1 PTE GYTK Farmakognóziai Intézet, 7624 Pécs, Rókus u. 2.

2 PTE ÁOK Orvosi Mikrobiológiai és Immunitástani Intézet, 7624 Pécs, Szigeti út 12.

${ }^{3}$ SE GYTK Farmakognóziai Intézet, 1085 Budapest, Üllői út 26.

${ }^{4}$ PTE GYTK Gyógyszertechnológiai és Biofarmáciai Intézet, 7624 Pécs, Rókus u. 2.

${ }^{5}$ PTE ÁOK Pathologiai Intézet, 7624 Pécs, Szigeti út 12.

${ }^{6}$ PTE ÁOK Farmakológiai és Farmakoterápiai Intézet, 7624 Pécs, Szigeti út 12.

${ }^{7}$ PTE Szentágothai János Kutatóközpont, 7624 Pécs, Ifjúság útja 20.

*e-mail: horvath.gyorgyi@gytk.pte.hu

A WHO 2015-ös felmérése alapján az alsó légúti megbetegedések a 10 vezető halálok listáján a harmadik helyet foglalják el. Mivel az antibiotikum-rezisztencia egyre nagyobb problémát jelent az egészségügyben, igény mutatkozik a kiegészítő terápiák iránt. Az illóolajokat inhalálással már régóta használják légúti betegségek kezelésében. Azonban a növényi eredetű kivonatokkal kapcsolatban is elvárás, hogy hatásosságuk több tesztrendszerben is bizonyítva legyen. Ezért munkánk során célul tűztük ki a fahéjkéreg-illóolaj antibakteriális és gyulladáscsökkentő hatásának tanulmányozását in vitro és in vivo modellekben.

A fahéjkéreg-illóolaj kémiai összetételét GC-FID/MS és SPME-GC-MS módszerekkel határoztuk meg. Az illóolaj antibakteriális hatását csőhígítás és gőzteres módszerekkel teszteltük légúti kórokozók ellen. A biofilmgátló hatást az illóolaj nanotechnológiai eljárással készült emulziójával végeztük. A gyulladásgátló hatást LPSindukált akut légúti gyulladás egérmodelljében tanulmányoztuk.

Az illóolaj fő komponense a transz-fahéjaldehid $(74,0 \%, 46,0 \%)$ volt mindkét analitikai rendszerben. Folyékony táptalajban a fahéjkéregolaj antibakteriális hatást mutatott a Streptococcus pyogenes, S. pneumoniae, S. mutans és Haemophilus influenzae, $H$. parainfluenzae ellen (MIC: $0,06 \mathrm{mg} / \mathrm{ml}$ ). A gőzteres vizsgálatban az illóolaj a Haemophilus törzsek ellen volt a leghatásosabb (MIC: 15,6 $\mu \mathrm{L} / \mathrm{L}$ ). A S. mutans biofilm-képzését a fahéjkéregolaj nanotechnológiai eljárással készült emulziója hatékonyabban csökkentette a Tween 80 és alkohollal készült mintákhoz képest. Az állatmodellben a fahéjkéregolaj inhalációja csökkentette a légúti hiperreaktivitást, szövettani képeken a makrofág-akkumulációt, viszont az MPO-aktivitást nem befolyásolta. 